\title{
Choroiditis due to hypersensitivity secondary to inactive ocular tuberculosis. Case report
}

\section{Coroiditis por hipersensibilidad secundaria a tuberculosis ocular inactiva. Reporte de un caso}

\author{
Lucía Echevarría-Lucas ${ }^{1 *}$, M. Mar Góngora-Miñarro , Cristina Gómez-Cabrera', Margarita Jódar-Márquez², \\ and Juan J. Gómez-Fernández ${ }^{1}$ \\ 'Ophthalmology Service, Hospital Comarcal de la Axarquía, Vélez-Málaga; ${ }^{2}$ Ophthalmology Service, Regional University Hospital, Málaga. Spain
}

\begin{abstract}
Purpose: To describe that the eye, after healing its active infectious stage, reacts similarly against several systemic infectious processes that affect its structures, such as tuberculosis, Ebola, or AIDS (together with its opportunist infections). Case report: We report the case of a female patient that, after a successful treatment against ocular tuberculosis, developed a multifocal choroiditis due to delayed hypersensitivity, with more potential devastating effects than the active infection itself: inflammation of choroidal and retinal vessels, papillitis, and macular edema that, without treatment, may induce severe visual loss. The patient received short-term systemic corticosteroids and long-term maintenance with systemic immunosuppressants. Conclusions: Ocular inflammatory reactions due to hypersensitivity are more destructive than the direct infection by different pathogens since there may be an inflammatory reaction secondary to the immune recognition of infectious antigenic particles in the ocular structures. Treatment is based on verifying that the active infection has been controlled and, subsequently, initiating systemic corticoids or corticosteroid-sparing immunosuppressive agents.
\end{abstract}

Keywords: Choroiditis due to hypersensitivity. Ocular tuberculosis. Immune reconstitution syndrome. Immunosuppressants.

\section{Resumen}

Objetivo: Describir que el ojo, ante procesos infecciosos sistémicos diversos que afectan a sus estructuras, tales como tuberculosis, infección por virus Ébola o sida (con sus infecciones oportunistas), una vez curado de su fase activa infecciosa reacciona de manera similar. Caso clínico: Presentamos el caso de una paciente que, tras ser tratada con éxito de tuberculosis ocular, desarrolló una coroiditis multifocal por hipersensibilidad retardada, de efectos potencialmente más devastadores que la propia infección activa, con inflamación coroidea y de vasos retinianos, papilitis y edema macular que, sin tratamiento, conduciría a una gran pérdida visual. Para su control, precisó corticoides sistémicos a corto plazo e inmunosupresores sistémicos de mantenimiento a largo plazo. Conclusiones: Las reacciones inflamatorias oculares por hipersensibilidad son más destructivas que la infección directa de diversos patógenos, ya que pueden generar una reacción inflamatoria basada en el reconocimiento del sistema inmunitario de restos antigénicos infecciosos en las estructuras oculares. Comprobar el control de la infección activa y posteriormente introducir corticoides sistémicos o inmunosupresores ahorradores de corticoides tiene efectos muy beneficiosos.

Palabras clave: Coroiditis por hipersensibilidad. Tuberculosis ocular. Síndrome de recuperación inmunitaria. Inmunosupresores. Correspondence:

*Lucía Echevarría-Lucas

Antígona 1-3-L

Date of reception: 06-05-2020

Date of acceptance: $24-08-2020$

E-mail: luciaechevarria98@gmail.com

2604-1731/@ 2020 Sociedad Mexicana de Oftalmología. Published by Permanyer. This is an open access article under the CC BY-NC-ND license (http://creativecommons.org/licenses/by-nc-nd/4.0/). 


\section{Introduction}

The advance in the knowledge of infectious diseases allows us to deepen the approach to poorly defined ocular conditions so far. In the case of tuberculosis (TB), the ocular manifestations can be diverse, depending on the etiopathogenesis of the process ${ }^{1}$. Thus, on the one hand, the conditions derived from the direct invasion of ocular tissues by the bacillus stand out, and on the other, the ocular inflammatory reactions produced by delayed hypersensitivity mechanisms, in which the immune system recognizes the traces of mycobacterial antigens in ocular structures and reacts against them ${ }^{2,3}$. Recognizing and differentiating them is essential, since the treatment is radically different. Ocular manifestations, if produced by the first mechanism, consist of choroidal tubercles and nodular scleritis; in the second, vasculitis and choroiditis are more frequently developed ${ }^{1}$. This last mechanism of generation of ocular inflammation, once the infectious process has resolved, is based on the recognition by the immune system of infectious antigenic remains in the ocular structures; it is a mechanism common to other infectious processes, such as Ebola virus disease ${ }^{4,5}$, syphilis, leptospirosis, borreliosis ${ }^{6}$, and AIDS, with its immune recovery uveitis (IRU) syndrome ${ }^{7,8}$.

\section{Clinical case}

A 66-year-old woman vaccinated with BCG (Bacillus Calmette-Guérin) in her youth. She referred a medical history of hypothyroidism and depression. No disorders or immunosuppressive treatments were reported. Four years earlier, she had developed a bilateral panuveitis $^{9}$ with peripheral choroidal and macular granulomas, and inflammation of the optic nerve in the right eye (OD) (Fig. 1 A). The left eye (OS) showed extensive areas of previous choroidal atrophy (Fig. 1 B). This condition was classified, in collaboration with the internal medicine service, as ocular TB, for presenting an intensely positive Mantoux test (> 10), which would exclude a post-vaccination result ${ }^{10}$ and positive smear microscopy in spontaneous sputum performed in three phases, making a Ziehl-Neelsen stain first, less specific, but which was positive, and then a culture in Lowenstein-Jensen medium, which was positive for Mycobacterium tuberculosis. However, chest radiography and pulmonary computed tomography were negative. Additional laboratory tests (angiotensin-converting enzyme [ACE], human immunodeficiency virus [HIV], and anti treponemal serology) were normal.
Antineutrophil cytoplasmic (ANCA) and antinuclear (ANA) antibodies were negative. All these results ruled out sarcoidosis, Wegener's granulomatosis, and infectious diseases such as syphilis and HIV, with all their associated immunosuppressive diseases. Finally, we made a diagnosis of disseminated tuberculosis with tracheal or laryngeal as well as ocular involvement. All these analyses and diagnostic tests were carried out after the patient granted informed consent and was aware of the diagnostic, therapeutic and scientific interest of her case.

She was successfully treated with a tuberculostatic protocol (isoniazid $75 \mathrm{mg} /$ day + rifampin $150 \mathrm{mg} /$ day + pyrazinamide $400 \mathrm{mg} /$ day + ethambutol $275 \mathrm{mg} /$ day) for 2 months, and then isoniazid and rifampin for 4 months. Given the severe ocular inflammation in the $\mathrm{OD}$, low doses of cortisone ( $30 \mathrm{mg} /$ day) were prescribed (Fig. 1 C). Five months after the ocular inflammatory process subsided, the patient had a severe visual loss in the OD $(<1 / 10)$, due to the appearance of a neovascular membrane on the scar of a tuberculous macular granuloma; therefore, she was subjected to treatment with antiangiogenics (ranibizumab $10 \mathrm{mg} / \mathrm{mL}$, one intravitreal injection per month for 3 months) (Fig. $1 \mathrm{D}$ and $\mathrm{E}$ ), obtaining a first remission of the process. However, 3 months later there was a recurrence that required two more injections, at a rate of one per month. After this, she had a visual acuity (VA) of $3 / 10$ in the OD (Fig. $1 \mathrm{~F}$ to I). Throughout this process, the VA of the OS was $10 / 10$, as there was no choroidal involvement at that time ${ }^{11}$, although, as noted, the retinographies (Fig. 1 B) showed areas of previous choroidal atrophy, which could correspond to some uncontrolled inflammatory process that spontaneously remitted without being diagnosed.

After complete remission of the process and carrying out a surveillance follow-up in which sporadic outbreaks of uveitis were detected in the OD (easily treated with topical corticosteroids), one year after the last injection of antiangiogenics in the OD she attended the emergency room with a VA decrease in the OS of 8/10, with anterior uveitis (+++) and macular edema (Fig. $2 \mathrm{~A}$ ). Referred back to the internal medicine service, the inactivity of the systemic tuberculosis process was verified by means of a new sputum smear (Ziehl-Neelsen stain) and culture (Lowenstein-Jensen medium), which were negative, and an IGRA (Interferon Gamma Release Assay) in blood. In addition, a bronchioalveolar lavage was performed, which was also negative. Repeated radiological tests, such as chest computed tomography, were also negative. In addition, another 


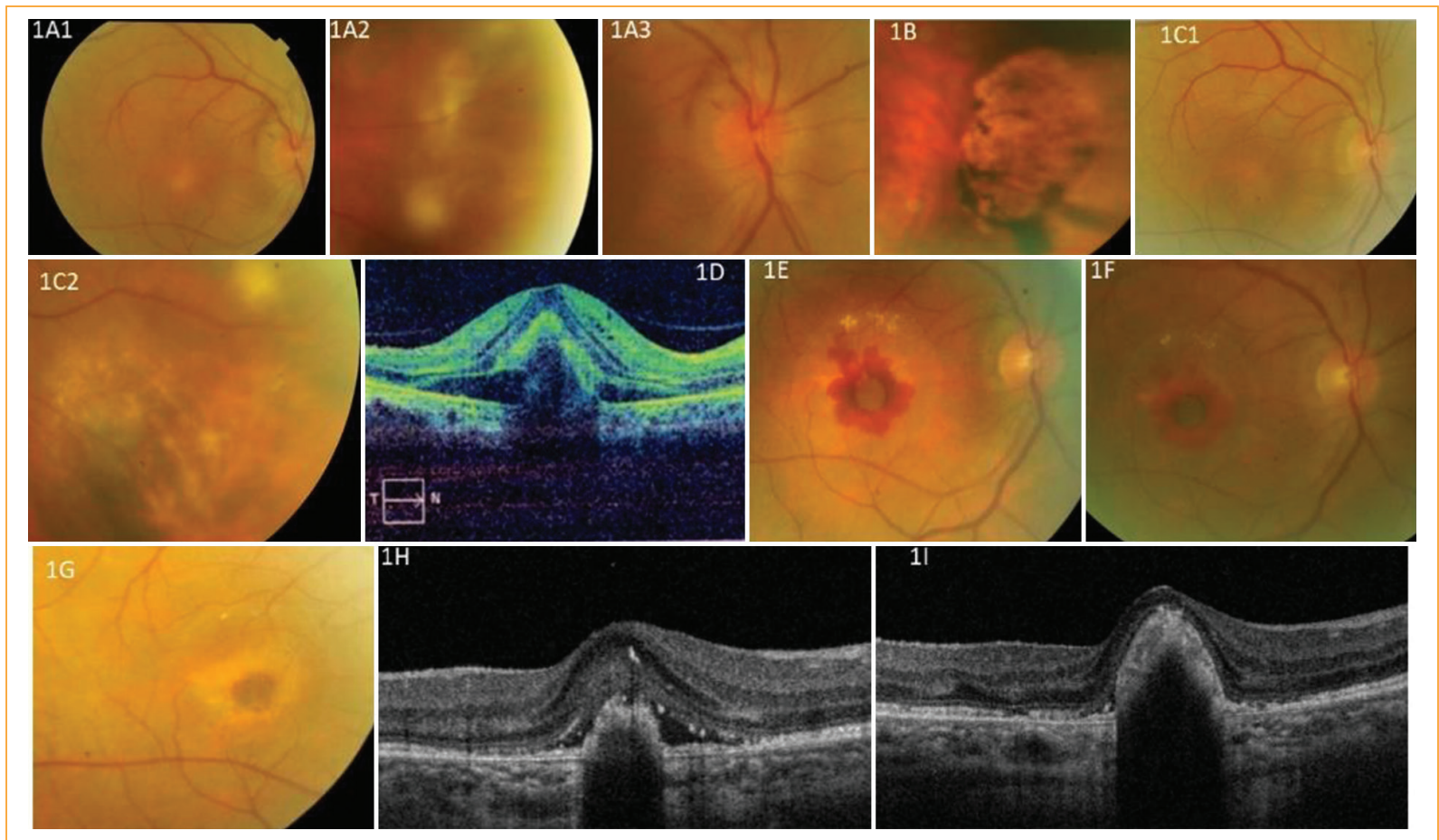

Figure 1. A1: presence of macular choroidal granulomas in OD. A2: peripheral choroidal granulomas in OD.

A3: inflammation of the optic nerve in OD. B: extensive areas of previous choroidal atrophy in OS. C1 and C2: healing after treatment with tuberculostatics and corticosteroids in OD. D: neovascular membrane by optical coherence tomography in OD. E: neovascular membrane over a tuberculosis macular granuloma scar in OD.

F, G, H and I: the resolution of the membrane in OD after five intravitreal injections of antiangiogenics.
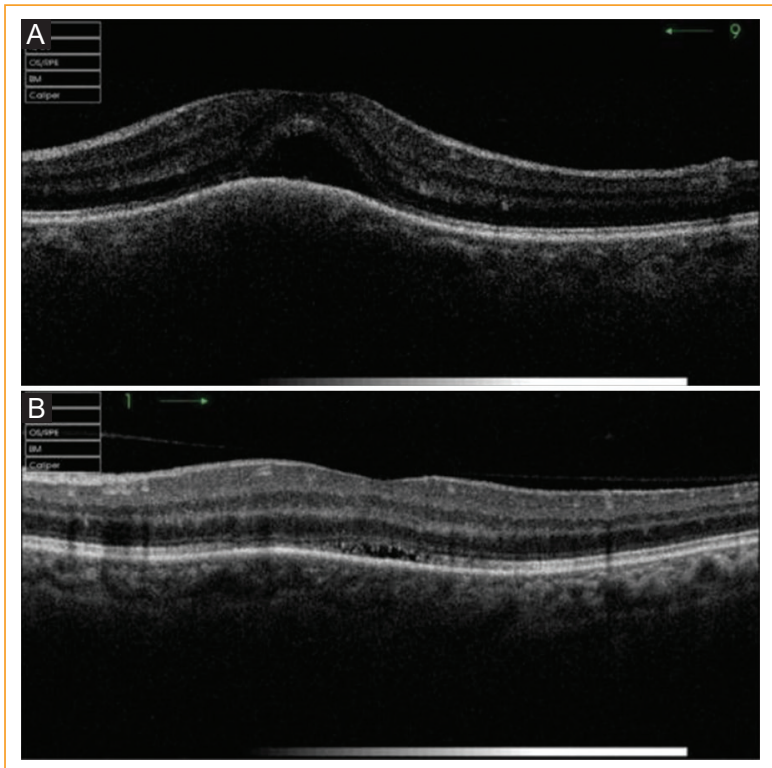

Figure 2. A: one year later, the first appearance of the inflammatory process in the OS after the active tuberculosis had been cured. Inflammatory macular edema with retinal pigment epithelium detachment. B: gradual remission of macular edema and retinal pigment epithelium detachment in the OS after initiation of systemic corticosteroids. battery of diagnostic tests for ACE, HIV, and antitreponemal antibodies (ELISA) was carried out, in case they had been carried out earlier in the window period, and again also a determination of ANAs and ANCAs; as well as HLA B27 and HLA B7 tests, but all were negative. Consequently, systemic corticosteroids (deflazacort $30 \mathrm{mg} /$ day) and topical corticosteroids were initiated, reducing inflammation (Fig. 2 B) and achieving a complete visual recovery (10/10). After a month, the OS process reappeared with a new visual decrease and foci of peripheral choroiditis and papillitis, in addition to anterior uveitis (Fig. 3 A). Systemic (deflazacort 30 mg/ day) and topical corticosteroids were reintroduced, and the process remitted again (Fig. 3 B). However, when tapering the systemic corticosteroid therapy, the inflammatory symptoms reappeared (Fig. 4 A and B), which led to the introduction of systemic azathioprine (three $50 \mathrm{mg}$ tablets/day) as a long-term maintenance treatment to prevent relapses. With this, it was finally possible to discontinue the systemic corticosteroids and control the inflammatory process (Fig. $4 \mathrm{C}$ to $\mathrm{E}$ ). It was possible to preserve a final visual acuity in the OS of $8 / 10$. The patient has currently been on the same dose 


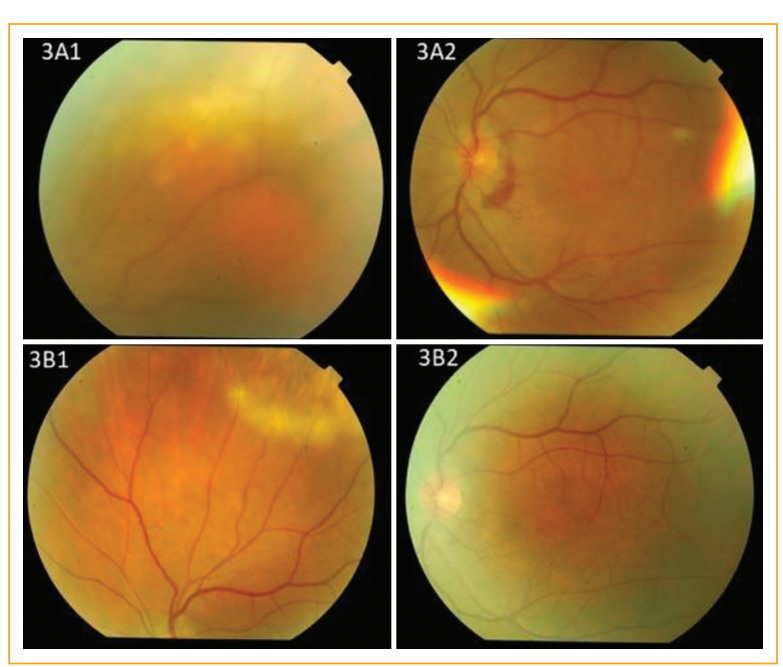

Figure 3. A1 and A2: one month later, second appearance of the inflammatory process in the OS after active tuberculosis had been cured. Peripheral choroidal (A1) and optic nerve (A2) inflammation. B1 and B2: new remission of the process after the reintroduction of systemic corticosteroids.

of azathioprine for 6 months, and it is expected to reduce a $50 \mathrm{mg}$ tablet/day every 2 months, depending on the clinical response, as long as the condition does not reactivate.

\section{Discussion}

The behavior of the immune system and its ocular manifestations acts in a similar way against infectious agents of very different types. In the case of TB, the ocular manifestations may not be caused by the active infection of the bacillus that invades the eye, but, once the infection is treated, a delayed type IV hypersensitivity reaction to various antigenic components with an enormous destructive power may appear, even worse than the active infection itself ${ }^{3}$.

Administration of the purified protein derivative (PPD) of tuberculin has been reported as a cause of panuveitis, suggesting a type IV hypersensitivity reaction in the ocular structures ${ }^{11}$. Likewise, a multifocal choroiditis very similar to the Vogt-Koyanagi-Harada syndrome has been described 5 days after the administration of PPD, which improved with the systemic use of corticosteroids $^{12}$.

The case we present is especially striking because two inflammatory processes with the same infectious etiology, but with different mechanisms of action, rarely coincide in such an orderly manner: on the one hand, an inflammatory disorder caused directly by an active infection (the bacillus), and later, when it had been treated and had remitted, a hypersensitivity reaction due to the same infectious agent that had already been effectively treated; all in the same patient and in a delayed timeline, but easy to follow and link together.

This behavior of activation of an ocular autoimmune reaction against an infection already in remission was described years ago in the inflammatory syndrome of IRU in HIV-positive patients, which was part of the spectrum of immune reconstitution inflammatory syndrome (IRIS), even though it is not exactly a delayed hypersensitivity process, since it starts in immunosuppressed patients. IRU is an ocular inflammatory condition that develops in patients with AIDS who suffered from cytomegalovirus retinitis (CMVR), but whose process at that time was inactive $\mathrm{e}^{7,8}$ and their immune status had improved thanks to the administration of antiretroviral therapy; this happened in an average of 20 weeks from the increase in CD4 lymphocyte count (although it varied from months to years later), beginning with an inflammatory condition with vitritis, papillitis and macular edema, which produced a significant loss of vision. None of the patients with IRU had reactivation of CMVR, unlike the other IRIS (unmasked and paradoxical immune recovery retinitis). The administration of systemic corticosteroids protected against $\operatorname{IRU} \mathrm{I}^{7,8,13,14}$, so it was first-line treatment, but it was contraindicated in the other syndromes. Therefore, it was very important to know and distinguish IRU from CMVR relapse, because the treatment for both disorders was very different. In the case of CMVR reactivation, specific antivirals against cytomegalovirus (oral valganciclovir) would be initiated, at first without corticosteroids, since systemic corticosteroids were contraindicated in the early stages of reactivation, favoring the extension of $\mathrm{CMVR}^{7,8}$.

Of course, although IRU shares some similarities with the TB autoimmune process we describe, since both are autoimmune inflammatory processes in already inactive infections, they have marked differences, since there is previously an underlying disease in IRU (HIV) that has caused immune suppression and after the administration of antiretroviral therapy, the CD4 count increases and the viral load decreases by more than one logarithm (in base 10), producing an immune reconstitution ${ }^{14}$. In contrast, as in this case, the choroidal autoimmune reaction due to tuberculosis always occurs in a patient with preserved immunity and no additional systemic diseases. 


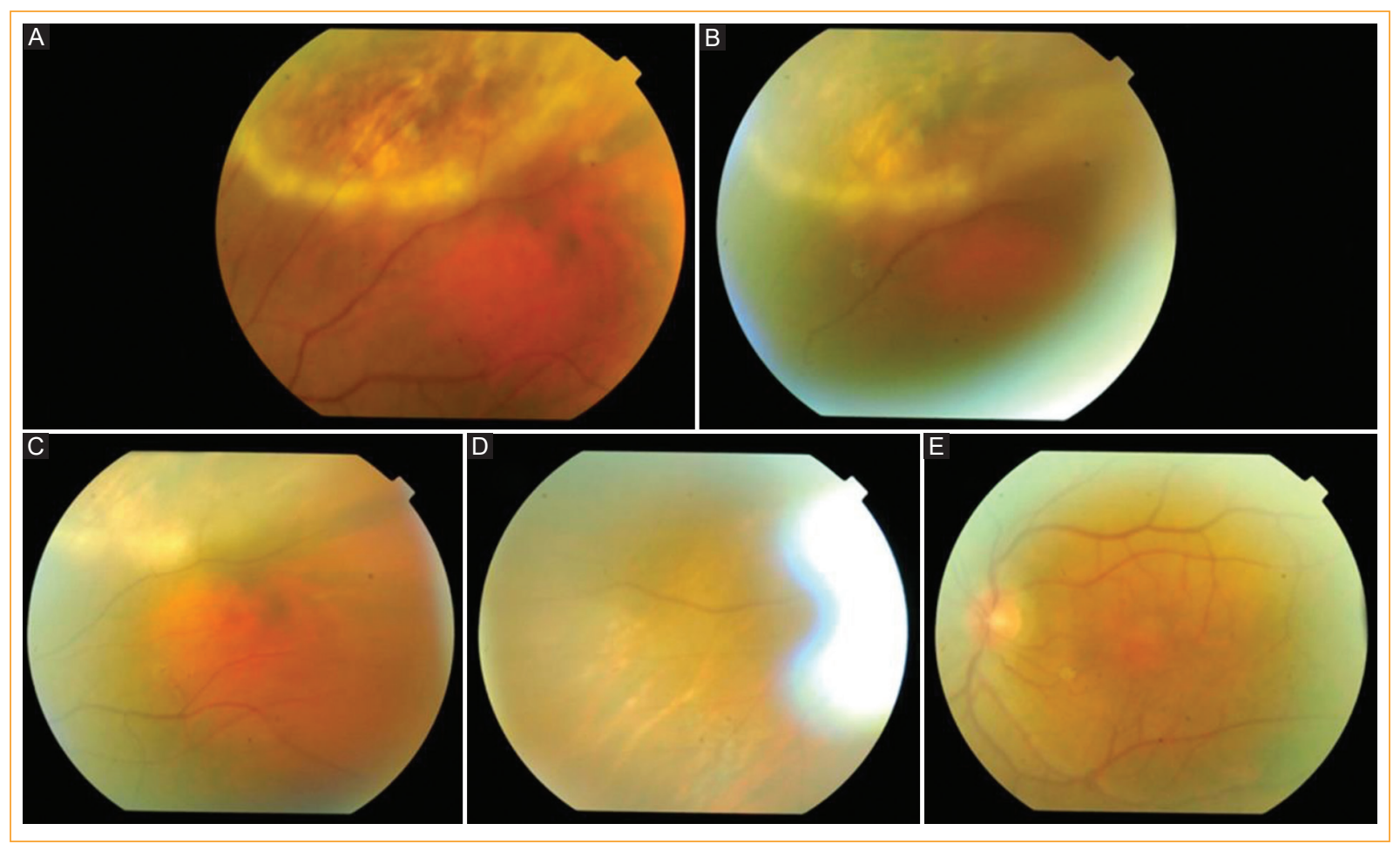

Figure 4. A and B: one month later, as corticosteroid therapy was tapered, the inflammatory process in the OS began to reappear again. C, D and E: with the introduction of systemic azathioprine, the inflammatory process in the OS is controlled and systemic corticosteroids were discontinued.

Another issue of great interest is the uveitis observed in survivors of the Ebola virus disease ${ }^{4}$, which in some cases produce a significant visual loss. These cases of uveitis were observed in $13-34 \%$ of Ebola virus disease survivors. Posterior uveitis and panuveitis were especially described, with VA worsening to $20 / 400$ in $39 \%$ of affected eyes in patients from Liberia. Polymerase chain reaction for Ebola virus detection in the aqueous humor of this patients by anterior chamber paracentesis was negative, so it seems that in most cases there was no presence of the virus ${ }^{4,5}$.

As in the aforementioned case of TB, the pathogenesis of uveitis in patients recovered from Ebola virus disease could be due to the hypersensitivity reaction to residual viral RNA antigens in the cells of the different ocular structures, with good evolution if patients can access drugs such as topical corticosteroids or oral prednisone. However, in the case of the Ebola virus, as it is such an unknown and fatal disorder, antiretroviral therapies (favipiravir) are administered preventively 48 hours before corticosteroid treatment ${ }^{4}$.

This paradoxical worsening mechanism after administration of specific treatments against infectious agents was first described in patients with early syphilis, although it has also been observed in neurosyphilis, ocular syphilis, and cardiovascular syphilis. Proposed mechanisms in the Jarisch Herxheimer reaction (JHR) include endotoxin release from organism death, delayed hypersensitivity, and decreased suppressive mechanisms. JHR is also common in leptospirosis and borreliosis ${ }^{6}$.

In our clinical case, the patient had had systemic TB with extensive retinal ocular repercussions, especially in the OD, which was treated with tuberculostatic drugs and systemic corticosteroids. However, once TB remitted, and the general condition of the patient improved, an ocular hypersensitivity reaction started as previously mentioned in the contralateral eye, which had been affected by uveitis to a lesser degree, although there was surely a less symptomatic mycobacterial spread with extensive choroidal atrophy perhaps due to an undetected previous process.

Like IRU or uveitis secondary to Ebola virus disease, this condition was successfully treated with systemic corticosteroids, without reinitiation of tuberculostatic drugs, since all tests indicated that it was not a case of infectious relapse. However, probably due to the high concentration of antigens of the TB 
bacillus in the ocular cells, the inflammatory process reappeared when the dose of systemic corticosteroids was reduced. For this reason, azathioprine was introduced at a dose of $150 \mathrm{mg} /$ day as a corticosteroid-sparing therapy, and cortisone was tapered, trying to avoid the problems that the long-term use of systemic cortisone would entail in the medium term. Azathioprine was used for its special role in preventing the proliferation of cells involved in the determination and amplification of the immune response. In addition, it has been considered effective for the treatment of various types of posterior panuveitis and uveitis, especially for serpiginous choroiditis, a disorder with a certain relationship to TB and with a related etiologic mechanism. Other therapeutic options would have been methotrexate ${ }^{13}$, administered successfully in some types of hypersensitivity reactions and with an added tuberculostatic effect. However, finally, the inflammatory process was controlled with the immunosuppressive drug (azathioprine), that has been used for 6 months without new inflammatory reactions, considering tapering at a rate of one tablet every 2 months, until achieving final control of the ocular inflammatory disorder.

\section{Conclusions}

The behavior of ocular conditions secondary to autoimmune reactions by several infectious agents has similar evolutions and treatments.

Eliminating active TB, surviving the Ebola virus or curbing AIDS-related opportunistic eye diseases does not ensure control of eye disease. Once infectious diseases have been eliminated, autoimmune ocular inflammatory reactions are sometimes more destructive than the direct infection of the microorganism itself.

Monitoring the control of active infection and subsequently introducing systemic corticosteroids and, as in our case, administering corticosteroid-sparing immunosuppressants in case of relapses (azathioprine, among others), can have very beneficial effects in the medium- and long-term for control of this type of uveitis.

\section{Conflicts of interest}

The authors declare no conflicts of interest.

\section{Ethical disclosures}

Protection of human and animal subjects. The authors declare that no experiments were performed on humans or animals for this study.

Confidentiality of data. The authors declare that they have followed the protocols of their Institution

on the publication of patient data.

Right to privacy and informed consent. The authors have obtained the written informed consent of the patients or subjects mentioned in the article. The corresponding author is in possession of this document.

\section{References}

1. Shakarchi FI. Ocular tuberculosis: current perspectives. Clin Ophthalmol Auckl NZ. 2015;9:2223-7.

2. Adán Civera A. Avances en el diagnóstico y tratamiento de las infecciones intraoculares. Monografías de la Sociedad Española de Oftalmología; 2012. $168 \mathrm{p}$.

3. Tenorio-Guajardo G, Ramírez-Casanova E, González-Rodríguez E. Tuberculosis ocular. Serie de casos en el Hospital General de México. Rev Médica Hosp Gen México. 2014;77:17-23.

4. Shantha JG, Crozier I, Yeh S. An update on ocular complications of Ebola virus disease. Curr Opin Ophthalmol. 2017;28:600-6.

5. Shantha JG, Mattia JG, Goba A, Barnes KG, Ebrahim FK, Kraft CS, et al. Ebola Virus Persistence in Ocular Tissues and Fluids (EVICT) Study: reverse transcription-polymerase chain reaction and cataract surgery outcomes of Ebola survivors in Sierra Leone. EBioMedicine. 2018;30:217-24.

6. Ganesh SK, Abraham S, Sudharshan S. Paradoxical reactions in ocular tuberculosis. J Ophthalmic Inflamm Infect. 2019;9:19.

7. Robinson MR, Reed G, Csaky KG, Polis MA, Whitcup SM. Immune-recovery uveitis in patients with cytomegalovirus retinitis taking highly active antiretroviral therapy. Am J Ophthalmol. 2000;130:49-56.

8. Song M-K, Azen SP, Buley A, Torriani F, Cheng L, Chaidhawangul S, et al. Effect of anti-cytomegalovirus therapy on the incidence of immune recovery uveitis in AIDS patients with healed cytomegalovirus retinitis. Am J Ophthalmol. 2003:136:696-702.

9. Concha del Río LE, Garza León MA, González Rubio Medina E, Recillas Gispert C, Voorduin Ramos S, Ruiz Cruz M. Guías mexicanas para el manejo de uveítis no infecciosa en adultos. Centro Mexicano de Enfermedades Inflamatorias Oculares (CMEIO); 2019.

10. Red Nacional de Vigilancia Epidemiológica. Protocolo de vigilancia y alerta de tuberculosis. Sevilla: Junta de Andalucía; 2011. Disponible en: https://www.juntadeandalucia.es/export/drupaljda/salud_5af95879cd47b_pr_tuberculosis2011.pdf.

11. Echevarría Lucas L, Medialdea Hurtado ME, Villena Irigoyen O, De Ramón Garrido E. Granuloma tuberculoso macular asociado a membrana neovascular tratado con terapia anti-factor de crecimiento endotelial vascular. Archivos de la Sociedad Canaria de Oftalmología. 2018;29:77-83.

12. Cano Parra J, Díaz-Llopis M. Drug induced uveitis. Arch Soc Esp Oftalmol. 2005:80:137-49

13. Julián K. ¿TB or not TB? El dilema de la uveítis asociada a tuberculosis. Oftalmol Clin Exp. 2013;6:35-44.

14. Ruiz-Cruz M, Alvarado de la Barrera $C$, Ablanedo Terrazas $Y$, Reyes Terán G. Proposed clinical definition for cytomegalovirus-immune recovery retinitis. Clin Infect Dis. 2014;59:298-303. 